\title{
Poola intertekstuaalsed meemid COVID pandeemia kohta
}

\author{
Dorota Brzozowska \\ Opole Ülikooli keeleteaduse instituudi korraline professor \\ dbrzozowska@uni.opole.pl \\ Władysław Chłopicki \\ Jagielloniani Ülikooli inglise keele osakonna keeleteaduse professor \\ chlopicki@gmail.com
}

\begin{abstract}
Teesid: Artikli eesmärk on anda ülevaade COVID-19 pandeemia kulust Poolas ja selle humoorikast kuvandist. Koroonaviiruse erinevatel etappidel kasutati sealses ajakirjanduses ja sotsiaalmeedias nalju ja meeme, mis kajastasid kiireid muutusi koroonarindel. Analüüsitav materjal sisaldab üle 300 meemi ja kommentaari. Need on kogutud veebruarist maini 2020. aastal, st viiruseteemalise huumoriloome haripunktis, autorite isiklikelt WhatsAppi ja Facebooki kontodelt. Naljad pilavad piiranguid, seadusemuudatusi, parlamendivalimisi, päevauudiseid teistest koroonaga võitlevatest riikidest ja seovad teemaga ka hooajaliste pühade, näiteks lihavõtete, motiive. Universaalsete, kõikjal maailmas rändavate huumoritekstide kõrval tõusid esile kultuurispetsiifilised teemad, mis kajastasid Poola sotsiaalseid ja poliitilisi olusid. Analüüs tuvastab intertekstuaalseid huumorimehhanisme ja osutab keerukatele kultuurilistele viidetele, mis on nende aluseks. Intertekstuaalsed vihjed kasutavad näiteks elemente Poola sotsialismiajastu filmidest, maalikunstist, poliitelust, kuid viitavad ka universaalsetele motiividele, näiteks loomameemidele.
\end{abstract}

Märksõnad: intertekstuaalsus, koroonapiirangud, meemid, sotsialism, stereotüübid

\section{Sissejuhatus}

COVID-19 pandeemia, mis puhkes 2020. aasta veebruaris, on maailma dramaatiliselt muutnud. See on toonud pikaajalisi muutusi ka Poola poliitilisse ja sotsiaalsesse ellu, ning pannud aluse uuele huumori- ja meemidelainele. Selles artiklis anname ülevaate põhilistest teemadest ja nende käsitlemisel kasutatavatest huumorimehhanismidest, mis põhinevad (mitmekihilistel) intertekstuaalsetel viidetel ja mida kasutati Poola valitsuse pandeemiavastaste meedete pilamiseks. 


\section{Intertekstuaalne huumor}

Neal Norrick osutab, et intertekstuaalsus "esineb juhul, kui üks tekst viitab või vihjab mõnele teisele äratuntavale suulisele või kirjalikule tekstile või diskursuselõigule" (Norrick 1989: 117). Intertekstuaalsust (kultuurisisest ja kultuuridevahelist) tuleks seega käsitleda kui olulist nähtust, mis ühendab suhtluskanalit, inimesi ja sõnumit. Internetikultuuri tõusu ja levikuga on see termin omandamas üha tähtsamat positsiooni. Huumoriuurimise kontekstis on see tähistanud huumoriteksti seotust mõne teise, varasema tekstiga, nt paroodia puhul (Ross 1998). Intertekstuaalsed vihjed toimivad vastavalt auditooriumi tähendusruumile ja selle ulatusele. Ilmselgelt pole alati ja iga intertekstuaalse teksti puhul võimalik välja tuua ühekorraga kõikide viidete algpunkti ja inspiratsiooniallikaid (Coulson 2015), kuid nende väljatoomine on informatiivne nii globaalsete trendide kui lokaalsete traditsioonide kirjeldamisel (Laineste \& Voolaid 2016: 28).

Nostalgilised intertekstuaalsed viited vanadele nõukogude-aegsetele motiividele (Laineste 2012) on Kesk-ja Ida-Euroopa meemides olulisel kohal. Isegi kui see tundub praegu absurdne ja keegi ei soovi seda uuesti läbi elada, kutsutakse naljade, teleseriaalide, muuseumide ja turismiobjektide kaudu sotsialismiaega pidevalt tagasi (Laineste \& Voolaid 2016: 29).

Intertekstuaalsusega on lähedalt seotud transmeedialisuse mõiste, mis tähendab kahe või enama samast või eri meediast pärineva kuid sarnase tarbijaskonnaga teksti koostoimet: toetamist ja esile tõstmist (Spiridon 2015: 260; vt ka Ryan 2008).

Intertekstuaalsust võib defineerida kui kahe või enama teksti koosesinemist, mis võtab erinevaid vorme (nt tsitaat, plagiaat või vihje). See on üks viiest transtekstuaalsuse avaldumisviisist, mille all mõeldakse siinkohal mehhanisme, mis suhestavad kas avalikult või vihjamisi üht teksti teis(t)ega (Genette 1997). Teised neli transtekstuaalsuse tüüpi on paratekstuaalsus, mis viitab teksti tähendust mõjutada võivatele ümbritsevatele sõnumitele ja kommentaaridele; metatekstuaalsus, mis kommenteerib, viitab või mainib selgelt algteksti; arhitekstuaalsus, mille puhul paigutatakse tekst konkreetse(te) žanri(te) raamesse; ja hüpertekstuaalsus, mille puhul hüpertekst muudab, täiendab või laiendab hüpoteksti, näiteks tõlge, järg või paroodia (Lanir 2019).

Huumor, mis kasutab intertekstuaalseid (eelkõige metatekstuaalseid ja transmeedialisi) mehhanisme, suurendab seeläbi huumoritarbijate sihtrühma ühtsust, viidates neile teada olevatele tekstidele. Teisest küljest võib intertekstuaalsuse lisafunktsiooniks olla - üsna huumorile sarnaselt - püüd lähendada ja ühendada inimesi rasketel aegadel, vähendada olukorra ebakindlust, võimaldada eneseidentifitseerimist ja rühmakuuluvuse määramist, suurendada sõnumi saatja usaldusväärsust ja edasi anda emotsioone (Davis 2008: 554). 


\section{Internetimeemid}

Internetimeemid on olnud juba mõnda aega huumoriuurijate tähelepanuväljas. Edukad meemid (Knobel \& Lankshear 2008: 6) sisaldavad ühte või mitut järgmistest tunnustest: (1) huumorielemente (nt absurdi, paroodiat, siseringinalju); (2) intertekstuaalsust (peidetud ristviited popkultuurisündmustele, inimestele, nähtustele); ja/või (3) kummastust tekitavaid (nt pildilisi) vastandamisi (Laineste \& Voolaid 2016: 32).

Huumorisuhtluses osalemine, näiteks meemide jagamine, neile reageerimine või nende jäljendamine, osutab uudsele intertekstuaalsuse vormile (Tsakona \& Chovanec 2020: 15). "Intertekstuaalsusel on ennastedendav motivatsioon ja efekt, eriti kui intertekstuaalse seose sihtpunkt on kultuuriliselt keskne, tähendusrikas tekst. Kui teksti loojad või tarbijad esitavad end kui eksperte, kes suudavad neid intertekstuaalseid seoseid mõista ja menetleda, tõestavad end seeläbi kui "haritud" ja "kirjaoskajaid" inimesi, kes on teadlikud "kaasaegsetest", "olulistest", "kesksetest", "moekatest" intertekstidest. Intertekstuaalsusel võib seega olla indiviidi sotsiaalset tähtsust tõstev mõju" (Tsakona \& Chovanec 2020: 16).

Dorota Brzozowska ja Władysław Chłopicki (2019) analüüsivad meeme kui visuaalse huumori liiki, mis põhineb (etniliste sihtmärkidega meemide puhul) vastuolulistel etnilistel stereotüüpidel. Internetihuumori-teemaline sissekandes raamatus Encyclopedia of Humor Studies loetletakse mõningaid meemitüüpe:

1. Engrish - naljakad fotod või tekstid Lõuna-Aasiast, kus kasutatakse vigast inglise keelt;

2. Reaction Photoshops - pildid, mille loomisel on kasutatud pilditöötlustarkvara, nt Adobe Photoshopi, et laialt levinud fotosid (naljakamaks) muuta;

3. Lip-Synch / lyp dub - videolõigud, milles üks või mitu inimest teevad, nagu laulaksid mõnda tuntud laulu;

4. LOLCats - pildid kassidest, mida täiendavad keeleliselt vigased pildiallkirjad (nn LOLSpeak - keeruline, mittestandardne, lapselik - või kassilik internetis levinud inglise keel);

5. Advice Animals - looma- või inimesepildid, mille pildiallkiri rõhutab sellega kaasas käivat stereotüüpi või omadust;

6. Rage Comics - amatöörlik koomiksistiil, milles kujutatakse erinevaid ekpressiivse ilmega nägusid, kellest igaüht iseloomustab teatud karakter (Shifman 2014: 392).

Huvitav on tõdeda, et meie andmestiku näited kuuluvad peamiselt kahte nimetatud kategooriasse: 2. Reaction Photoshops ja 5. Advice Animals. 


\section{Poola huumoritraditsioon}

Poola huumoril on pikk ja rikkalik ajalugu, mille dokumenteeritud ajalugu ulatub keskaega. Sellel on palju erinevaid žanre ja tüüpe, ning traditsiooniliselt võib seda leida eriilmelistest allikatest nagu proosa, luule, komöödia, satiir, kabaree, aga ka erinevatest kanalitest nagu ajakirjandus, film, raadio, televisioon, nüüd ka internet.

Huumorivormidest on levinud näiteks paroolid ja ütlused, libavanasõnad, aforismid, postrid, karikatuurid, satiirilised joonistused, kabareelaulud, poliitiline huumor, etniline ja regionaalne huumor, laste huumor jpm. Poolas on olnud palju huumorivõtmes kirjutavaid romaani- ja näitekirjanikke ning poeete, mõned kirjandusperioodid on huumoriloome poolest eriti silmapaistvad, nagu näiteks Noor-Poola liikumine eelmisest (19.-20.) sajandivahetusest. Juba varases Poola riigis, aga eriti 19. sajandil ja kahe maailmasõja vahel, oli kesksel kohal poliitiline huumor (nt 19. sajandi ajakirjandushuumor). Huumorit on kasutatud laialdaselt ka reklaaminduses. Etniliselt on poola huumor mitmekesine ja piirkonniti varieeruv: juudi, vene, leedu, valgevene, saksa, armeenia, masuuria, kašuubi kogukondadel on oma huumor, aga tuntud on ka linnapiirkondade huumor - Lvovi, Varssavi ja Krakovi spetsiifiline huumoritraditsioon, ning selle kõrval ka maapiirkondade eriilmeline naljapärimus, nt Lõuna-Poola mägiste alade elanike naljad (vt Chłopicki \& Brzozowska 2017). Need on huumori alaliigid, mida tasub uurida ja mida on ka jõudumööda uuritud (vt nt Brzozowska \& Chłopicki 2012: 12). Sotsialismiaja huumoritraditsioonis (1945-1989) paistis silma võimuesindajate pihta suunatud pilge (vt nt Davies 2011 ja tema teooria vaimu ja mateeria vastuolust naljades) ja absurdihuumor elust raudse eesriide taga (vt Davies 1998).

See artikkel keskendub poola huumorile, mille vallandas COVID-19 viiruselaine.

\section{Meetod}

Analüüsiti meeme ja kommentaare, mis koguti koroonaviiruse pandeemia esimese laine ajal veebruarist maini 2020. aastal. Kogumiskeskkonnaks oli eelkõige artikli autorite isiklikud Facebooki ja WhatsAppi kontod, ning sinna postitasid nende sugulased, lähedased sõbrad ja tuttavad ning kolleegid. Materjal peegeldab seega uurijate isiklikke eelistusi ning nende suhteid inimestega, kes nendega huumorit jagasid ja kellega neil on aja jooksul tekkinud huumorivahetusel põhinev lähedane suhe (Norrick 2014: 419). Umbes 300 meemi 
moodustavad huumorikorpuse kõige iseloomulikuma osa. Pärast maid 2020 vähenes meemide arv (nagu langes ka vajadus uudses olukorras hakkama saada). Esialgu oli meemide peamine teema COVID pandeemia, pärast seda aga lihavõtted, mis sageli kandsid viiteid pandeemiaolukorrale, ning veelgi hiljem muutus põhiteemaks poliitika, sest Poolas plaaniti presidendivalimisi. Kuigi koroonateemalist huumorit jagati ka pärast maid 2020, oli seda palju vähem kui enne, ja see pole kindlasti võrreldav pandeemia algusaegade intensiivse naljavahetusega. Materjali kogumine lõpetati, kui meemid ja naljad hakkasid korduma.

Analüüsiks valisime meemid, mida võib pidada kohaliku huumoritraditsiooni järgivaks ja mis viitavad poola-spetsiifilistele kultuuriteadmistele filmi- ja kujutava kunsti vallas. Need hõlmavad mälestusi sotsialismiajast - näiteks filmidest ja meeldejäävatest karakternäitlejatest -, mis osutavad paralleelidele mineviku ja tänapäeva vahel ning kommenteerivad humoorikal moel COVIDpandeemia aegset absurdset reaalsust. Seda valikut toetab hiljutine uurimus, mis sedastas, et kuni $30 \%$ poola meemidest sisaldab viiteid kohalikule kultuurile, eelkõige filmikunstile (vt Norström \& Sarna 2021).

Meemide analüüsil peab arvesse võtma (1) nende visuaalset külge, sh seal kujutatud tegelasi ja nende kultuurispetsiifilisi hoiakuid, nende näoilmeid (nt naeru); (2) intertekstuaalseid viiteid näiteks filmistsenaariumitele, kunstiteostele jm ning nende seostamisele COVID pandeemiaga; (3) metatekstuaalsetele elementidele nagu pealkiri või puänt meemides või paroodiates; ja (4) visuaalse ja verbaalse suhted meemitsükli sees. Analüüsi käigus juhime tähelepanu erinevatele intertekstuaalsuse mehhanismidele, mis seovad minevikupraktikaid tänapäevasega (väljamõeldut tegelikuga, konteksti sihtmärgiga) ja mille vallandab visuaalne ja/või verbaalne element.

\section{Meemide analüüs}

300 meemi hulgast valisime 22 näidet, mis kõige paremini esindavad COVIDteemialisi meeme. Jagasime need kolme poola meemide puhul tavalisse tüüpkategooriasse, mis kasutavad: (1) kultuuriviiteid; (2) viiteid sotsialismiajastu poliitilisele elule ja selle paralleelidele tänapäevaga; ja (3) loomakujutisi. 


\section{Kultuuriviited}

\section{Komöödiafilmid}

Nostalgia vanade heade ja lihtsamate aegade järele (vrd Krikmann \& Laineste 2009), kui must oli mustem ja valge valgem, kõik olid nooremad ja elu lõbusam, on märgatav meemides, mis viitavad poola filmidele 1960. ja 1970. aastatest. Üks selle aja kultusfilmidest "Rejs" (Lõbusõit) on tüüpiline näide komöödiast, mis sisaldas varjatud poliitilist kriitikat ja üritas süüdimatu huumori abil kõikehõlmavast tsensuurist mööda hiilida. Filmi süžee on lihtne: grupp reisijaid sõidab mööda Visla jõge Varssavist Płockisse. Üks reisija tuleb pardale ilma piletita, kuid teised pardal viibijad arvavad, et ta on uus meelelahutuse eest vastutav laevatöötaja. Mees võtab selle rolli vastu vaidlemata omaks ja korraldabki mitmeid üritusi: viktoriine, maskiballi, kaptenipäeva jne. Meemis on laenatud kaader laeval toimuvast üldkoosolekust, mis parodeerib vabrikutes korraldatavaid tööliste koosolekuid ja teisi kommunistlikule propagandale pühendatud koosviibimisi. Joonisel 1 küsib üks töölisest, reisija, kelle rolli täidab kuulus poola näitleja Jan Himilsbach (andekas näitleja, kes ei käinud kunagi teatrikoolis), COVIDi-teemalise küsimuse, tundes muret selle üle, et ta peab nüüd end liiga tihti pesema ja see olukord võib kesta määramatu aja.

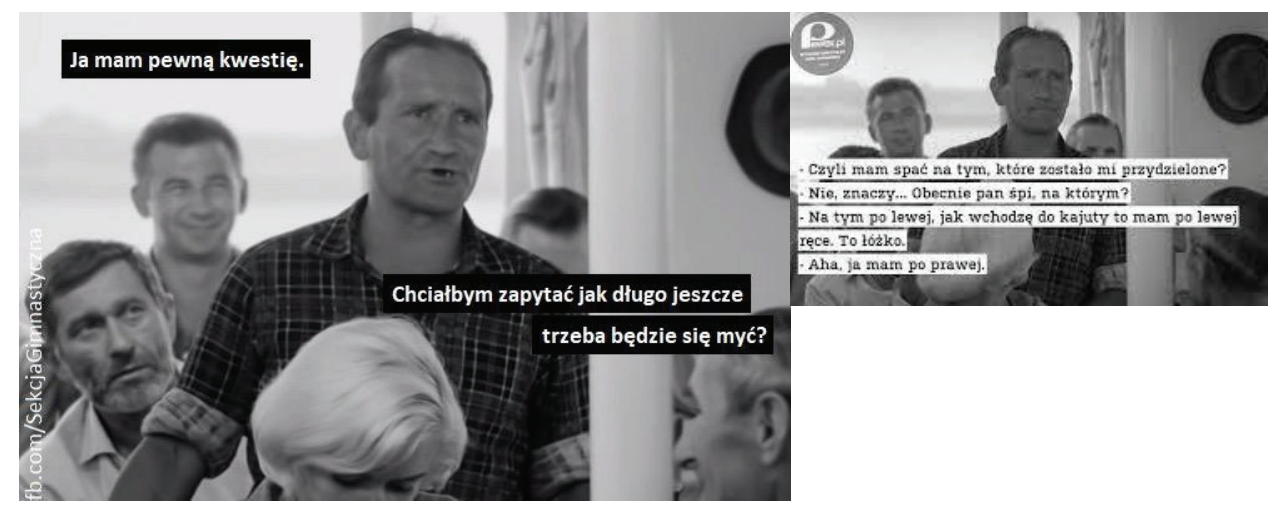

Joonis 1. Vasakul: COVIDiga seotud meem, mis kasutab kaadrit filmist"Rejs” (Lõbusõit) (1970). "Mul on küsimus. Ma tahaksin küsida, kui kaua me peame end veel pesema?" Paremal originaalne dialoog filmist. Küsimus: "Nii et ma pean magama selles voodis, mis mulle on määratud?” Vastus "Ei, noh, ... millises te praegu magate?” Küsimus: "Selles, mis on vasakul. Et kui ma sisenen oma kajutisse, siis on see vasakul. See voodi." Vastus: "Ahaa, no mul on see paremal pool." 
Joonised 2 ja 3 on intertekstuaalsed meemid, mis viitavad teisele komöödiafilmile pealkirjaga “Alternatywy 4" (Neli alternatiivi). Selle režissöör oli kultusliku mainega Stanisław Bareja, kes oli tuntud sotsialismiaja absurdi kujutajana. Tema nime järgi on isegi tuletatud uus sõna, bareism ( bareizm $^{1}$ ), mis tähistab teatud absurdiliiki. Filmi tegevus toimub tüüpilises Varssavi hruštšovkas, mis on pidevalt alles ehitusjärgus. Maja elanikud, kellest mõned on intelligendid ja ülikooli professorid, elavad väga kitsastes ja ebamugavates oludes. Korteriühistul on tugeva käega, kuid primitiivse mõtlemisega juht, kelle võimuses on nende elude korraldamine vaatamata inimeste eneste soovidele, ning kes võib korraldada väga lühikese etteteatamisega koosolekuid. Stseen, mida kasutatakse meemis (joonis 2), leiab aset ühes korteris korraldatud pulmapeol. Originaalis meenutavad kaks tegelast viinapudeli juures oma Teise maailmasõja aegseid võltsimiskuritegusid. Neile omistatud dialoog meemis viitab kätepesukohustusele ja karantiiniaegsele pereelule.

Joonis 2. Meem, mille aluseks on kaader filmist "Alternatywy 4" (Neli alternativi), osa 8: Abielu (1982-1983). "Saabunud on kohutavad ajad, härra. Inimesed peavad käsi pesema, toitu valmistama, lastega rääkima. Kui nii edasi läheb, hakkavad nad varsti ka raamatuid lugema.”

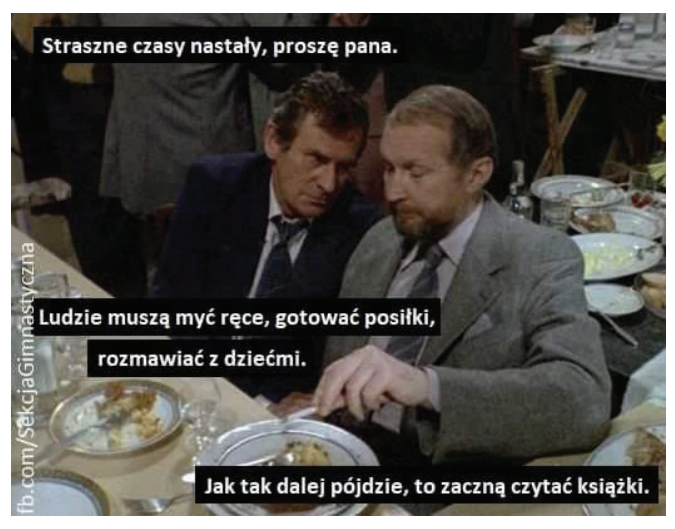

Meemis joonisel 3, mis on päris samast filmist, kujutatakse ühistujuhti, kes vestleb Kotekiga (tõlkes kassike), kraanajuhiga, kes haub juhi vastu salaplaani. Vestlus tundub sõbralik, kuid tegelikult teeb Kotek sellega aega parajaks, et ühistujuht ei märkaks, mida teised majaelanikud samal ajal maja ees korraldavad. Originaalis parodeerib dialoog ühise keele leidmise püüdu, isegi kui see tähendab nõustumist, mistahes absurdsete ideedega ühistujuht lagedale tuleb. Meemi dialoog viitab Jarosław Kaczyńskile, kes on vana poissmees, kel puudub pereelu kogemus, kuid kes sellest hoolimata rakendab pandeemia ajal pereelu mõjutavaid sanktsioone. 


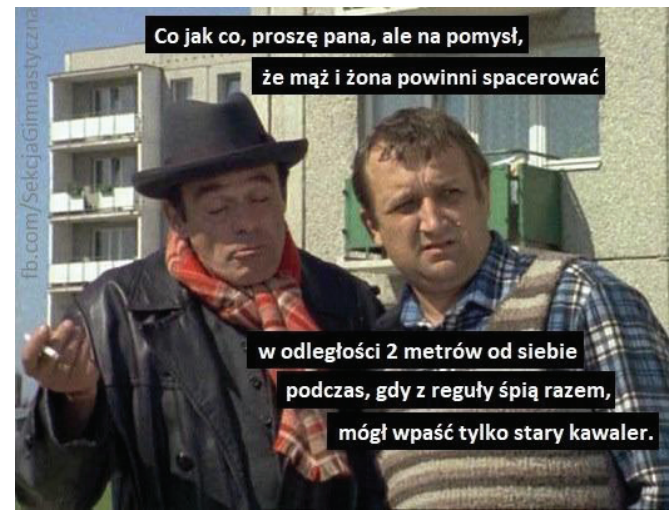

Joonis 3. Kaader filmist "Alternatywy 4" (Neli alternatiivi): "Ma kordan, härra, selle idee, et abielus naine ja mees peaksid kõndima teineteisest 2-meetrist distantsi hoides, olgugi et nad kodus kalduvad koos magama, on kindlasti välja mõelnud mingi vana poissmees."

Suur osa meemidest sisaldas intertekstuaalseid viiteid nii praegustele kui ka varasematele massikultuuri nähtustele. Joonis 4 on karikatuur, mis kujutab tüüpilist kõrtsistseeni, kus õllesed kliendid vaatavad telekat ja kommenteerivad nähtut. Siin on viide seriaalile "Korona królów" (Kuningate kroon), mis on populaarne ajalooline kostüümidraama Poola 14. ja 15. sajandi kuningatest. See on riigitelevisioonis eetris olnud alates 2018. aastast (2020. aasta oktoobri seisuga kokku üle 400 episoodi). Seriaal on pikaaegselt naljade sihtmärgiks olnud selle ebaloomulike dialoogide ja värskete, otsekui nõelasilmast tulnud kostüümide tõttu. Karikatuur joonisel 4 viitab ka Zenek Martyniukile (Poola popstaar ja disko-polo ${ }^{2}$ musikastiili esindaja), keda riigitelevisioon tugevalt toetab - näiteks tehti temast film "Zenek 2020". Jutumullis olev tekst kasutab sõnamängu, et ühendada korona kaks tähendust - koroonaviirus ja kroon.

Joonis 5 sisaldab viidet kultuuristereotüüpidele Lõuna-Poola mägismaalaste (górale) kohta. Neid tuntakse värvikate rahvariiete ja kultusliku teleseriaali "Janosik" järgi. Janosik (Slovakkias Juraj Jánošík) oli 18. sajandil Poola-Ungari piiril tegutsenud mägismaalasest röövel, kelle ütlused ringlevad poola keeles tänini. Kaks fotol kujutatud tegelast on Janosiku peamised kambajõmmid, kellel oli suur nõrkus toore liha, viina ja magamise vastu. Mägismaalasi kujutatakse kui inimesi, kes elavad lihtsat elu, harivad viljatut maad ja taluvad karmi talveilma. Nende eluvaated on üsna lihtsakoelised: nad armastavad vaba aega, raha, viina ja naisi, ja nende lemmikajaviide on turistide haneks tõmbamine (vt Chłopicki \& Brzozowska 2017 nende kohta käivatest anekdootidest). Sellele stereotüübile viitab ka joonis 5 . 


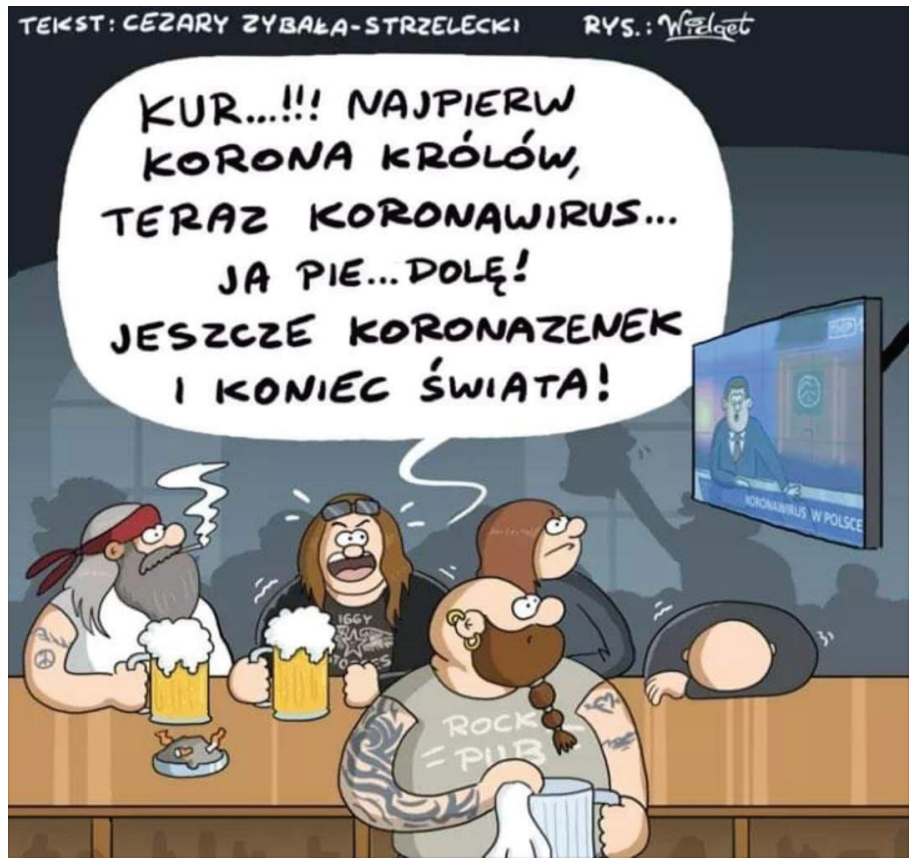

Joonis 4. Kõrtsikülastaja: "Kurat! Esiteks "Kuningate kroon", nü̈̈d koroonaviirus. Persse! Kui koroona-Zenek tuleb, on maailma lõpp käes!”

Joonis 5. Visuaal filmist "Janosik" (1974). Üks mägismaalasest röövel teisele: "Joo viina, istu oma perse peal ja ükski viirus ei kimbuta sind." (Originaalis riimub.)

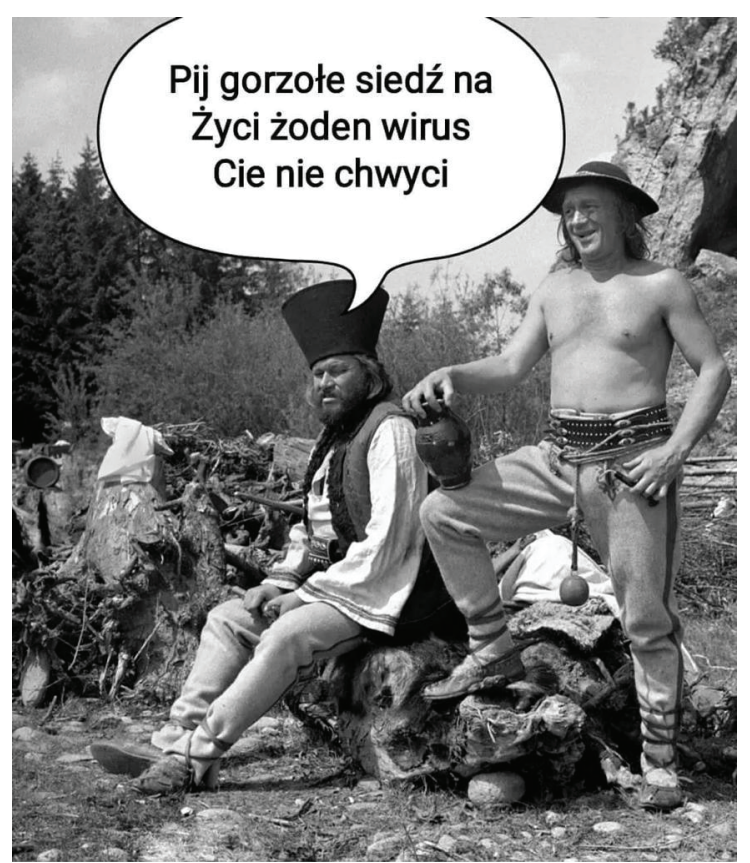




\section{Klassikalised maalid}

Pandeemia ajal tekkis hulgaliselt meeme, kus politseinikud, kes olid pilditöötlusprogrammiga lisatud kuulsatele poola maalidele, jälgisid seal toimuvat tegevust või sekkusid sellesse. Viidatakse rumala politseiniku stereotüübile, mis oli eriti levinud Poolas kommunistliku valitsuse ajal miilitsa kohta. ${ }^{3}$ Miilits oli sotsialismiajal selliste anekdootide sihtmärgiks nagu "Miks miilitsad käivad alati paarikaupa? - Üks oskab lugeda, teine kirjutada" või “-Ainult üks oskab lugeda ja kirjutada, ja teine peab sellel intelligendil silma peal hoidma”. Koroonakriisi alguses levinud meemidel (vt joonis 6) kandsid politseinikud näomaske, samas kui hilisemates (joonis 7) oli tendents kujutada politseinikke tuntud vanade maalide taustal, seljaga vaataja poole. Idee oli tõmmata tähelepanu politseinike sekkumise läbimõtlematusele ning piirangute põhjenduste absurdsusele.

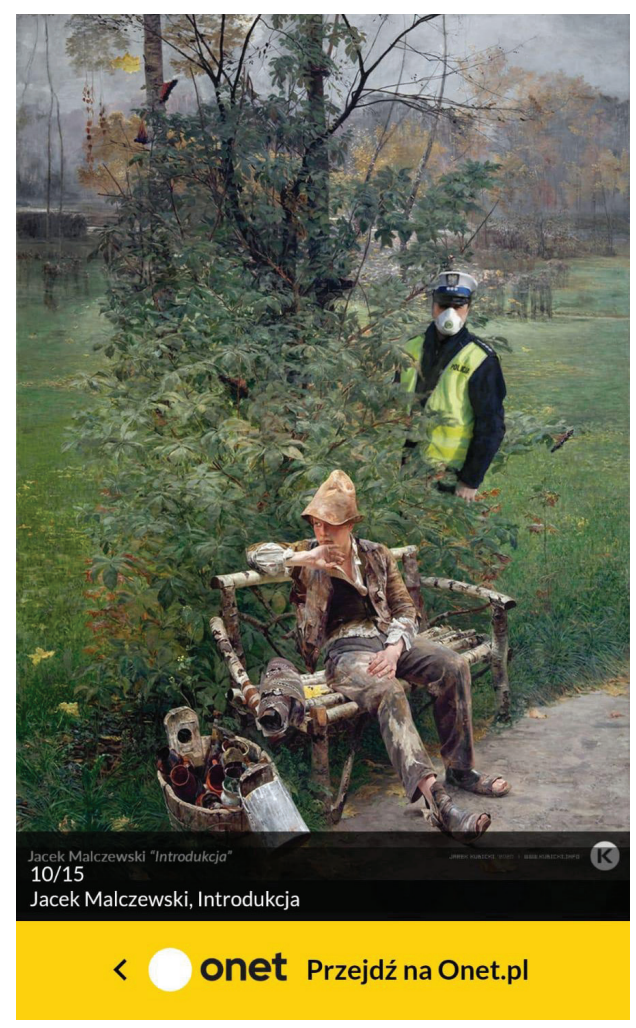

Joonis 6. Meem, mis kasutab sümbolisti Jacek Malczewski (1854-1929) maali "Malarczyk" (Kunstnik) (1890). Näomaskiga ja vormis politseinik tahab sekkuda kunstniku tegevusse. 
Joonis 7. Meem, mis kasutab Wtadystaw Podkowiński (1866-1895) maali "Szat uniesień” (Hullunud juubeldus) (1894), mis on väljas Krakovi rahvusmuuseumis. Politsei: "Mis on teie reisi eesmärk?" Naine hobuse seljas: "Ma lihtsalt hullun juubeldusest"

\section{Teised kultuuriviited}

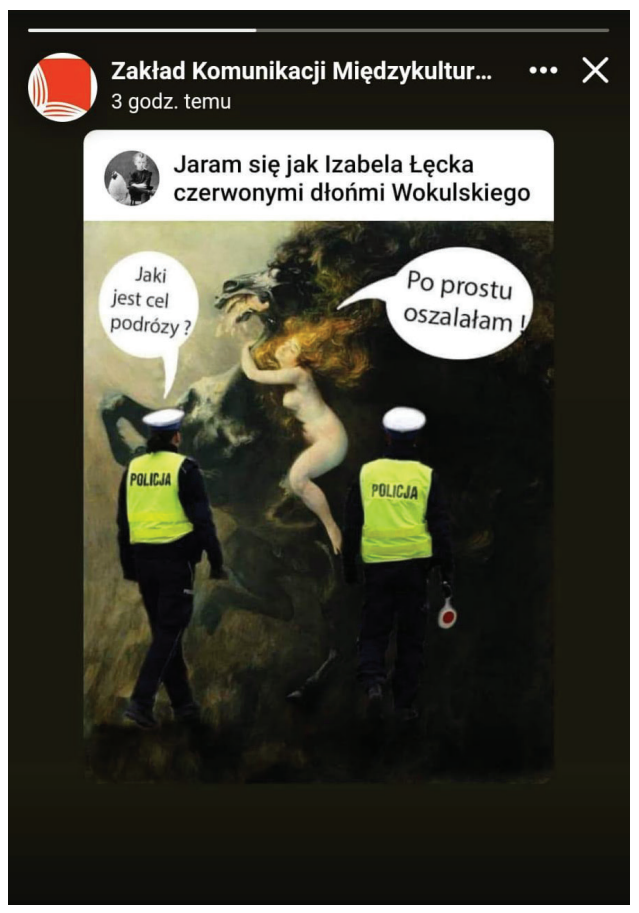

Kraków on üks vanimaid linnu Poolas ja selle elanike kohta on käibel mitmed stereotüübid: nad armastavad raha ja traditsioone, neil on oma murrak ja kirevad rahvariided. Lisaks sellele seostatakse Krakovi linna suduga, mis on sealset õhku reostanud juba üle poole sajandi, viimasel ajal eriti talviti. Poola valitsus üritab sudu ilma suurema eduta kontrolli all hoida. Joonisel 8 poseerivad krakovlased gaasimaskidega Waweli kindluse ees. Koht on tuntud selle poolest, et sinna on maetud enamik Poola kuningatest. Pildiallkiri teatab, et Krakówis teadsid ja tegutsesid inimesed (siin: teadsid, et on vaja kanda (gaasi)maski ja tegidki seda) märksa varem kui mujal.

Joonis 8. Krakówis kandsime me maske juba enne kui see populaarseks sai.

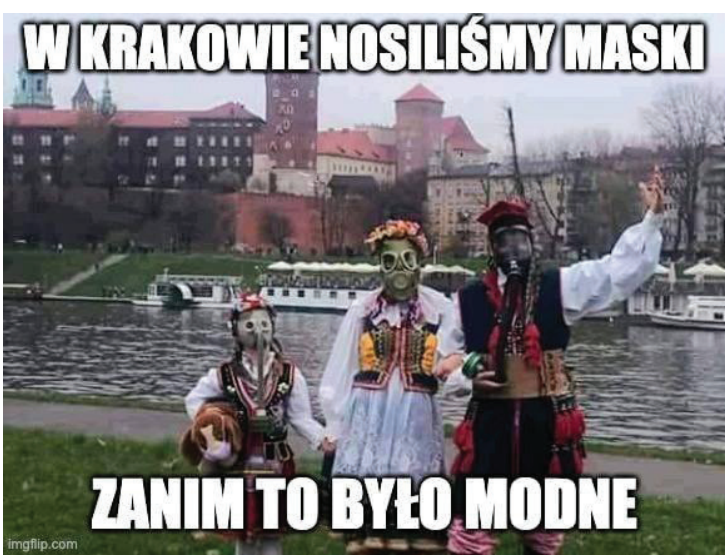




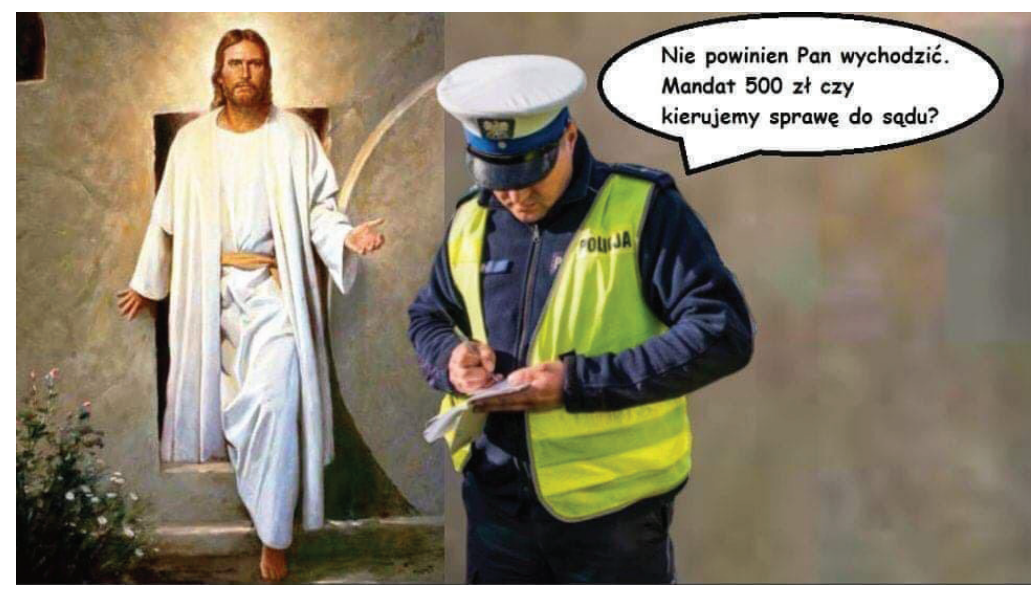

Joonis 9. Politsei: "Te ei tohiks väljuda. Kas maksate 500 zlotti või läheme kohtusse?"

Joonis 9 on näide usuteemalisest meemist, mida inspireeris koroonapandeemia kokkulangemine lihavõttepühadega. Suure nakatumiskordaja tõttu piirati pühade ajal Poolas, sügavalt katoliiklikus riigis, ülestõusmispühade tähistamist kirikutes; keelati ka perekondlikud kokkusaamised pikendatud nädalavahetusel, mil tavaliselt süüakse koos pidulikku hommikusööki ja soovitakse üksteisele häid pühi. Näiteks toodi paralleele Kristuse ülestõusmise asjaoludega - ka Kristus lahkus koopast, kuhu tema surnukeha oli maetud. See oli teemaks ka meemis (joonis 9), kus politsei üritab trahvida Kristust ülestõusmise eest. Lisaks sellele on pildil visuaalne vastuolu tänapäevase politseivormi ja Kristuse vanaaegse ürbi vahel.

Joonisel 10 näeme teist tüüpi intertekstuaalset meemi, kus põhimehhanismiks on sõnamäng tuntud poola modernismiajastu luuletaja Kazimierz Przerwa-Tetmajeri (1865-1940) nimega. Nali ise on juba vana ja näiteks kooliõpilaste seas ammu levinud: luuletaja esimene perekonnanimi Przerwa (mis osutab saksapärasele aadliseisusele: algselt Tettmayer von Przerwa) tähendab pausi või tühja kohta. Tema perekond kuulus küll väikeaadlike hulka, kuid nende soov näidata end põlisaadlina põhines ilmselt täielikult valeväidetel ${ }^{4}$ ja nime peenutsev, pseudo-aristokraatlik kõla on mitme põlvkonna poolakate meelest olnud koomiline. Joonisel 10 kasutatakse tema nime juhendina, kuidas tuleks ühistranspordis istuda. Tõlgendades tema esimest perekonnanime sõna-sõnalt saab olukorra, kus kaks reisijat, Kazimierz ja Tetmajer, peavad hoidma ühe nende vahele jääva istme vaba. 


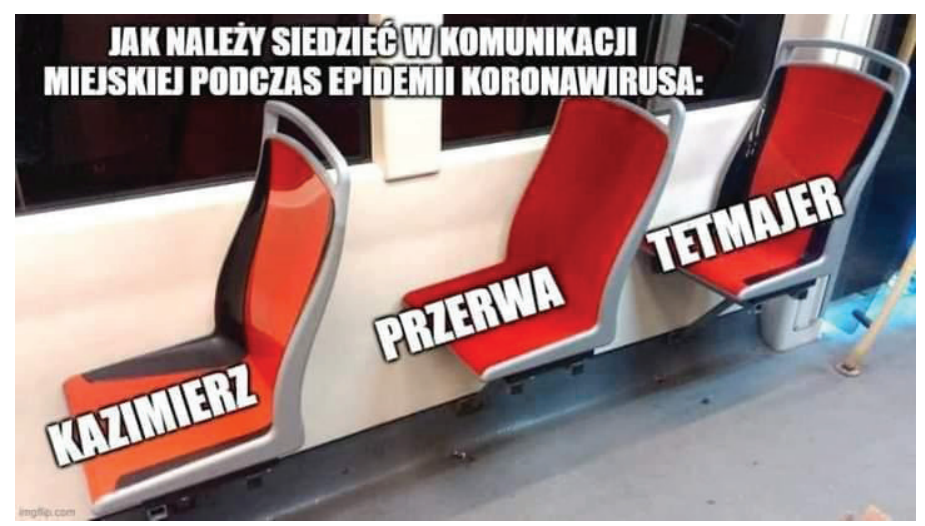

Joonis 10. Kuidas tuleks istuda ühiskondlikus transpordis koroonapandeemia ajal: Kazimierz - Przerwa (Paus) - Tetmajer.

\section{Viited Poola poliitilisele olukorrale}

\section{Elu sotsialismiajal}

Tüüpiline poola pandeemiahuumor viitab sageli riigi postsotsialistlikule taagale (vrd Krikmann \& Laineste 2009), seda mitte ainult kultuuris vaid ka poliitelus. Poolakad märkasid kohe sarnasust pandeemiapiirangute ja sõjaolukorra vahel, mille kuulutas pühapäeval, 13. detsembril 1981 välja tookordne kommunistist riigijuht kindral Wojciech Jaruzelski. See oli traumaatiline kogemus tervele põlvkonnale: piirangute tõttu ei tohtinud lahkuda oma elukohast, keelatud oli välismaale reisimine ja linnadevaheline liikumine välja arvatud (Poola ja vahel ka nõukogude) sõjaväe loal ja jälgimisel tehtud sõidud. Intertekstuaalse meemi (joonis 11) keskmes on naeratav kindral Jaruzelski, kes on just kelleltki kuulnud, et piirid on COVID-19 tõttu suletud. Meemi sõnum võib olla positiivne - me oleme üle elanud ka hullemaid aegu ja pandeemia ei suuda meid rööpast välja lüüa. Lisatähenduse annab kuupäevade kokkulangemine: seekord suleti piirid pühapäeval, 13. märtsil 2020. Kolmeteistkümnes kuupäev on poolakate kultuurimälus tähtsal kohal, ${ }^{5}$ sest ka pärast sõjaolukorra lõppu korraldati just iga kuu 13. kuupäeval selle meenutamiseks protestimarsse ja proteste. Peale selle usuvad poolakad (aga ka paljud teised rahvused), et 13 . ja reede on õnnetu päev. 


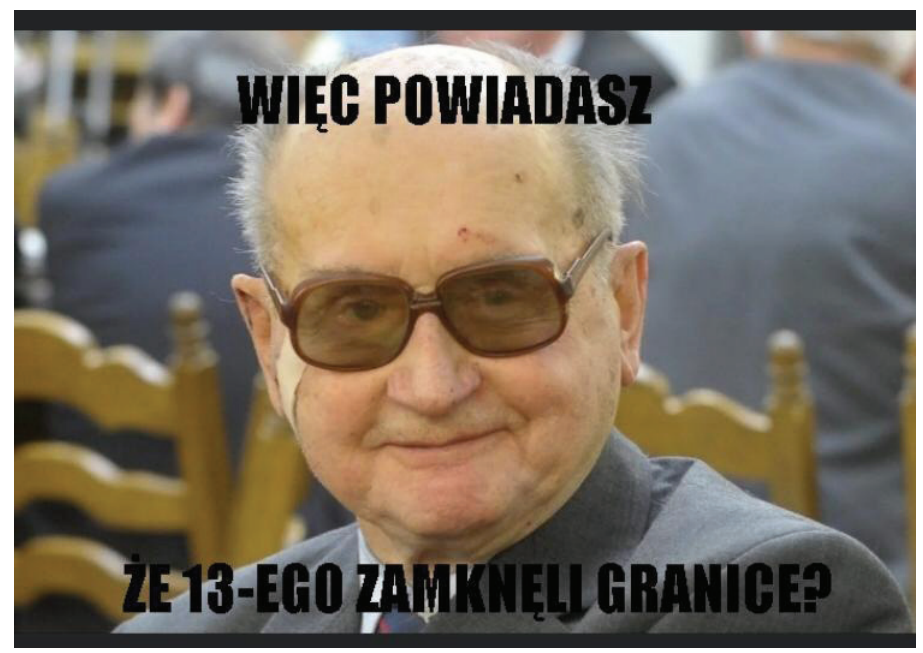

Joonis 11. Nii et sa siis ütled, et nad sulgesid riigipiiri 13ndal?

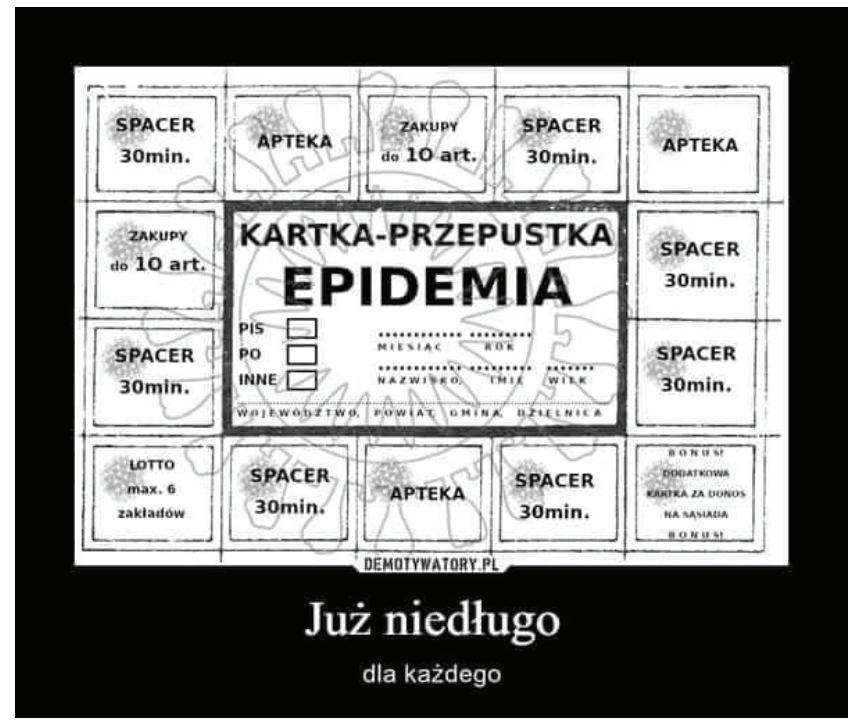

Joonis 12. Epideemia talongikaart. Keskel: "PIS", "PO", "muu". Kuu, Aasta, Perekonnanimi, Eesnimi, Vanus, Maakond, Linn, Linnaosa. Välisringil: Jalutuskäik - 30 minutit (7 talongi), Apteek (3), Osta kuni 10 kaupa (2), Loto - vali 6 numbrit (1), Boonus lisatalong naabri peale kaebamise eest. Pildiallkiri: "Peatselt kõigile kättesaadav". 
Sõjaseisukord piiras paljude kaupade müüki ja tarbimist, näiteks polnud saada põhitoiduaineid, alkoholi, kingi ja muud. Piirangud olid alanud juba varem, 1976. aasta kriisi paiku, kuid poolakad olid toidunormidega kokku puutunud ka seoses natside võimuletulekuga 1940. aastatel ja kommunistliku režiimi ajal pärast Teist maailmasõda. Komplekt talonge joonisel 12 nimetavad ihaldusväärseid "kaupu": 30minutiline jalutuskäik, visiit apteeki, võimalus osta kümme toodet, aga ka võimalus saada lisatalong oma naabri peale kaebamise eest. Talongil on ka koht, kus saab raporteerida oma parteilist kuuluvust ("PIS" (võimupartei), "PO" (opositsioonipartei) või “muu”). See viitab võimupartei autoritaarsusele, valimistulemuste varjamisele, samuti kalduvusele kasutada mittedemokraatlikke meetodeid opositsiooni tegevuse halvamiseks ja diskrimineerida neid kodanikke, kes ei kuulu PISi.

\section{Tänapäevapoliitika}

Poola COVID-19 meemid on erilised ka selle poolest, et jaanuaris 2020 paika pandud plaani kohaselt pidid 10. mail toimuma presidendivalimised. Pärast koroonaviiruse puhkemist kuu aega hiljem muudeti reegleid ja valitsus kuulutas välja kaugvalimised, et vältida viiruse levikut. Need oleksid olnud esimesed kaugvalimised Poola ajaloos, mistõttu võis karta, et need pole kõige paremini planeeritud. Otsus valimised üldse ära jätta kuulutati välja vaid kolm päeva enne määratud päeva ja sedagi seoses tõsise kriisiga valitsevas koalitsioonis. Joonis 13 kujutab kahte kaarti, mille ülesandeks on selgitada Poola valitsuse läbikukkumisele määratud kaugvalimiste plaani ja seda, et Poola valitsus korraldab valimisi irratsionaalselt ja valijatevaenulikult.

Joonis 13. Riigid, kus valimised on edasi lükatud. Riigid, kus plaanitakse valimisi korraldada.

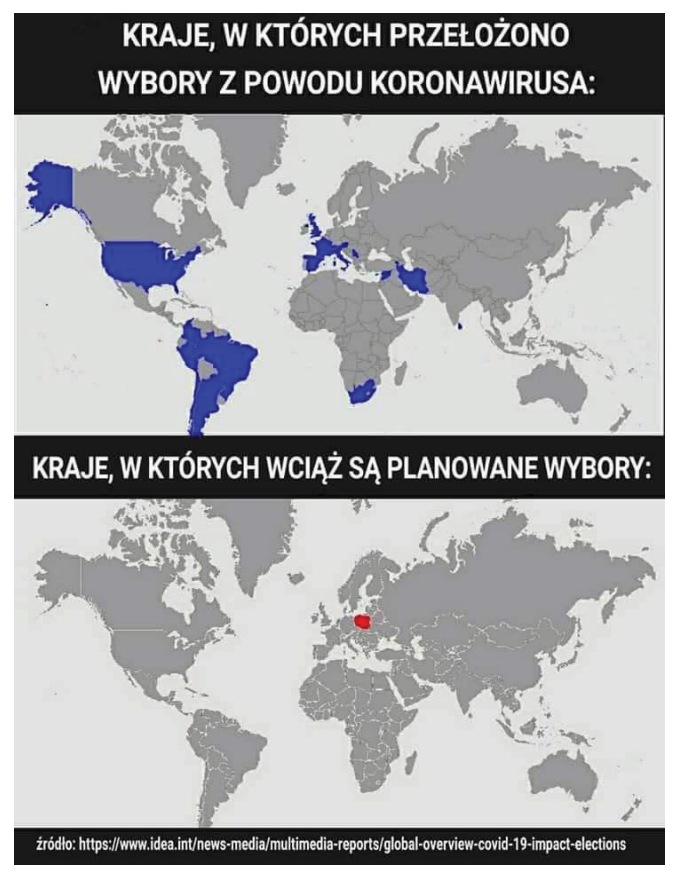


Paljud inimesed ei uskunud, et võimud siiski plaanivad valimiste läbiviimist vaatamata terviseriskidele ja võltsimisohule. Joonis 14 ütleb, et 1 . aprill on sel aastal hoopis 10. mail, tuues võrdusmärgi valimiste ja aprillinalja vahele.

\section{Ze względu na poważną sytuację, jaka panuje na calym świecie Prima Aprilis przeniesiono na 10 maja.}

Tervelt kahe kuu vältel märtsi algusest aprilli lõpuni 2020 üritasid ametnikud rahvast veenda, et valimised toimuvad nii nagu planeeritud, posti teel toimuvad valimised ei sea kuidagi ohtu valimistulemusi ja epideemia ei mõjuta kuidagi valimiste käiku. Valimiste korraldamist pandeemiaohu kõrghetkel kritiseerib joonisel 15 olev meem, kus oma tavapärast kunstlikku naeratust naeratav Poola president hoiab käes tuhaurni ja soovitab "Poolakad urni juurde!", mis kujundlikult tähendab kutset valima minna. ${ }^{6}$

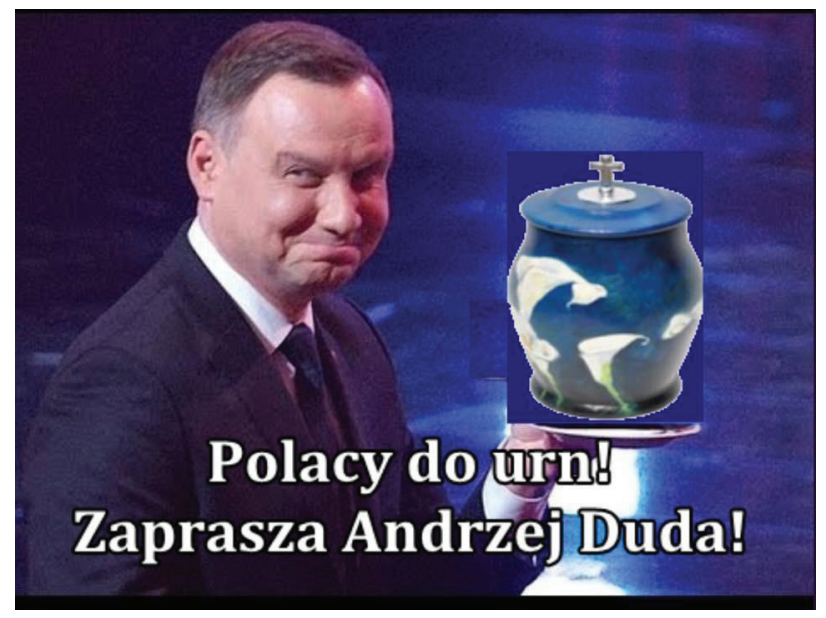

Joonis 15. "Poolakad urni/valmiskasti juurde!” [President] Andrzej Duda palub teid." 
Järgmine meem viitab kõige veidramale piirangule, mille Poola valitsus pandeemia vaoshoidmiseks välja mõtles, nimelt keelule metsa minna. See kehtis küll vaid nädala (3.-11. aprillini 2020), kuid sellegipoolest andis see inspiratsiooni mitmetele meemidele. Joonisel 16 on suur rahvamass, kes on kõik kohale tulnud selleks, et minna metsa kõndima pärast terve nädala kestnud keeldu. Kuigi tegu on fototöötlusega, näitab pilt, et sellised keelud pigem suurendavad nakkusohtu, sest kutsuvad kokku suuri rahvamasse ning lähevad seega vastuollu eesmärgiga, mida algselt taotleti.

Joonis 16. Esmaspäev Poola metsas.

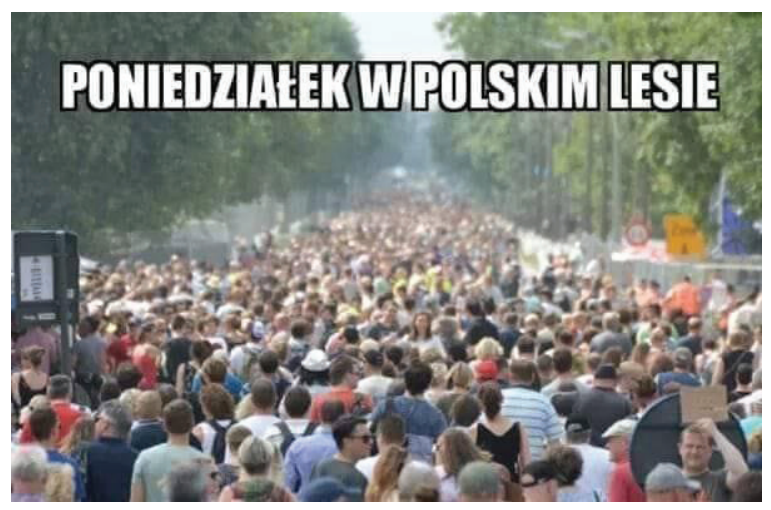

Poola intertekstuaalsed meemid viitavad ka teiste riikide poliitikutele, näiteks joonisel 17 seisavad kõrvuti kaks "poliitvennakest” Putin ja Lukašenka, kes pöörduvad Jarosław Kaczyński poole ja väljendavad oma lugupidamist selle eest, et ta julgeb korraldada valimisi pandeemia ajal. See on irooniline märkus Kaczynski konservatiivse poliitika pihta. Sõnavalik ("szacun" = lugupidamine) viitab noorte slängis levinud sõnale "szacunek" = lugupidamisekene), mida kasutatakse kaaslaste tegudele positiivse hinnangu andmiseks.

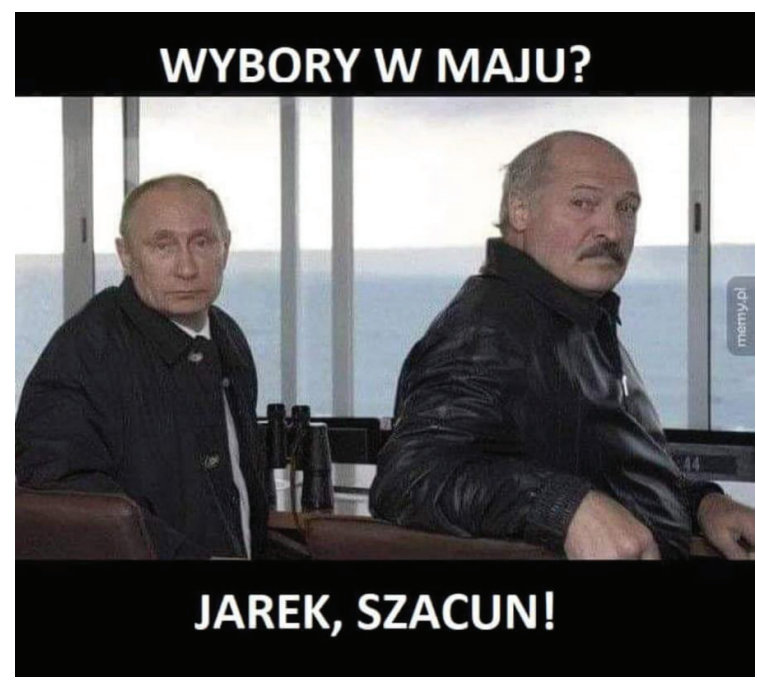




\section{Loomameemid}

Arvukate visuaalsete pandeemianaljade seas - aga ka meemide seas üldisemalt (Shifman 2014) - on üheks oluliseks tüübiks loomi kujutavad meemid, mis võivad samuti sisaldada poliitilisi ja kultuurilisi viiteid.

Joonisel 18 küsitleb politseinik kassi, kirjutades talle välja trahvikviitungit maski mittekasutamise eest. Kass vaatab politseinikku uskumatul ilmel. Kogu stseen on ilmselgeks kommentaariks mitmetimõistetavatele reeglitele näomaski kasutamise kohta.

\section{To mam myszy łapać w maseczce?}

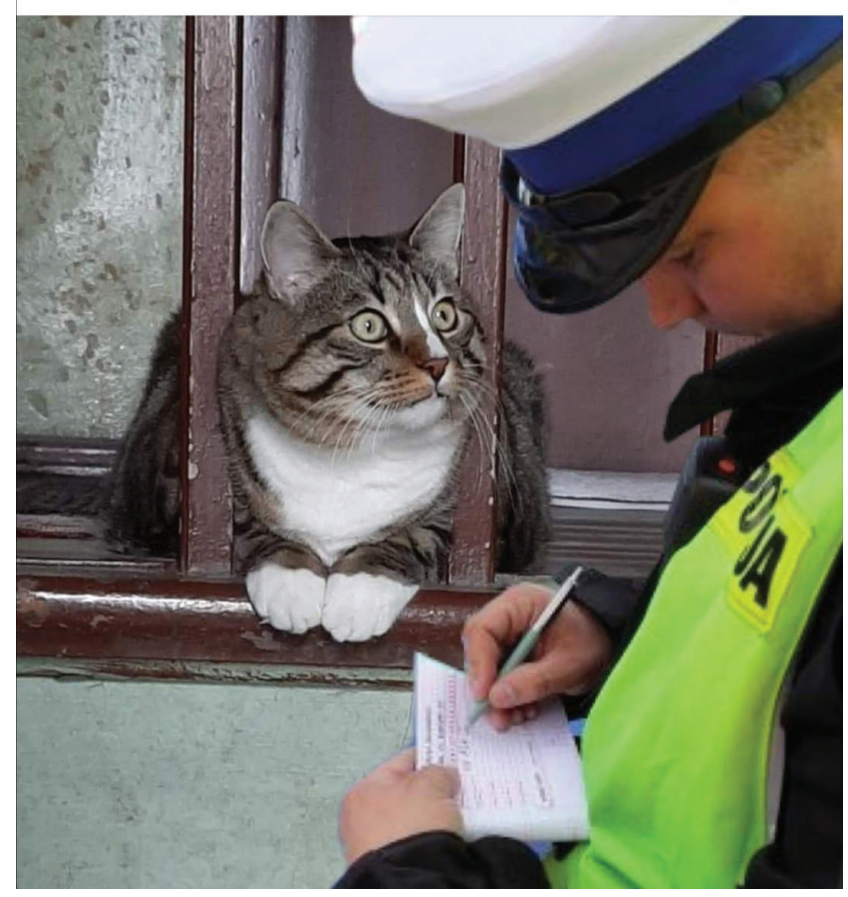

Joonis 18. Kass: "Nii et ma peaksin, mask peas, hiiri pü̈̈dma?"

Joonistel 19 ja 20 kujutatakse koeri, kasse ja muid koduloomi, kes oma näoilme ja kehakeelega annavad mõista, et inimeste käitumine (koduspüsimine, näomaski kandmine) pandeemialaine ajal on neile mõistatuseks. 


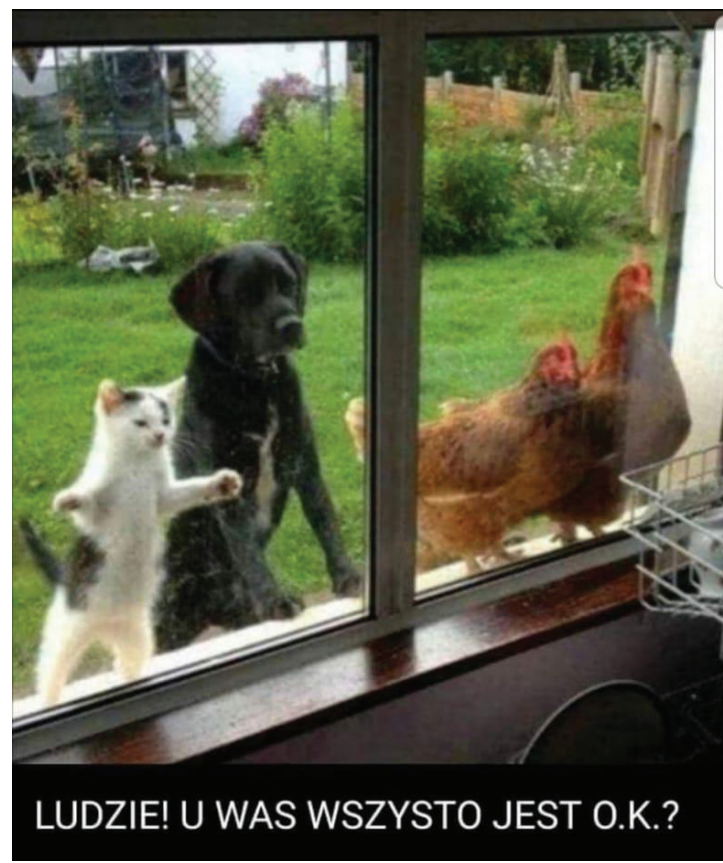

Joonis 19. Inimesed! Kas teiega on kõik korras?

\section{Co się dzieje ?? Dlaczego ludzie chodzą w kagańcach?}

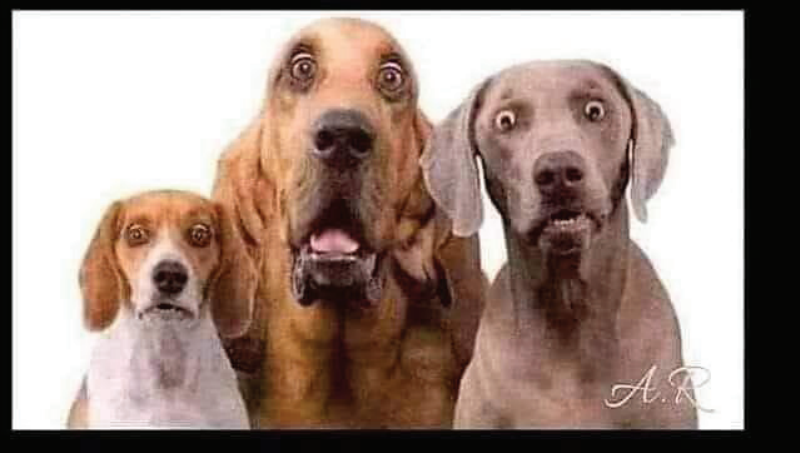

Joonis 20. Mis toimub?? Miks inimesed suukorviga käivad? 
Mõned loomameemid kasutavad intertekstuaalseid viiteid sotsialismiaja kultusfilmidele. Joonisel 21 on kujutatud ühte armastatuimat koera kinoekraanilt, Szarikut. Szarik oli nelja tankisti lahutamatu kaaslane seriaalist "Neli tankisti ja koer" (Czterej pancerni i pies), mis oli teleekraanidel esimest korda aastatel 1966-1970. Szarik oli alati valmis oma meeskonda abistama võitluses saksa vägede vastu, olenemata riskidest ja vigastustest. Joonisel 21 lamab Szarik (küll teisest tõust, kuid viitest nimele piisab) kurnatult diivanil, olles terve päeva pidanud saatma oma maja elanikke jalutuskäikudel. COVID-19 piirangud sisaldasid klauslit, et väljas võib kaks korda päevas jalutada vaid koeraomanik.

\section{To jest Szarik, jedyny pies w naszym 16-sto piętrowym bloku . Szarik był dzisiaj 50 razy na spacerze .}

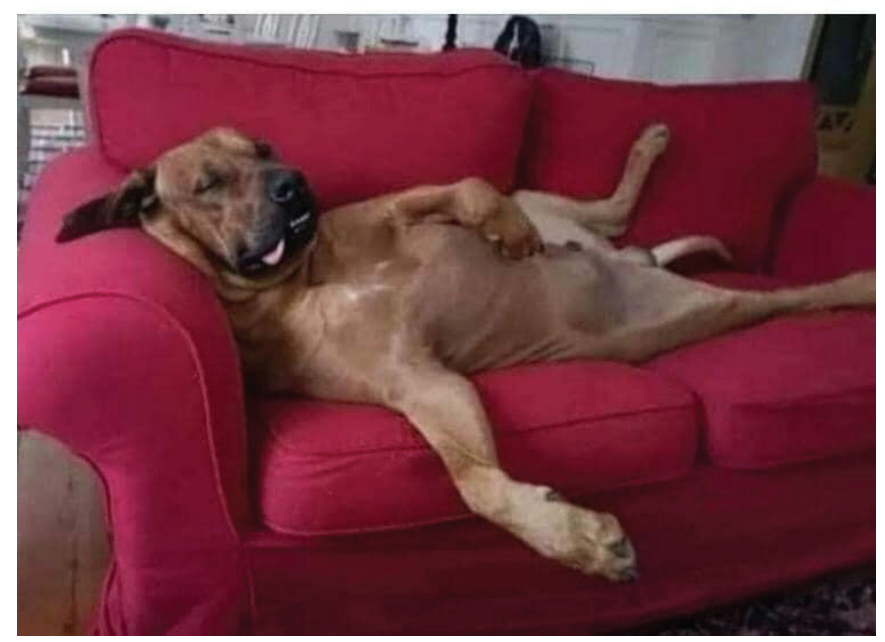

Joonis 21. See on Szarik, ainuke koer meie 16korruselises kortermajas. Teda on täna jalutama viidud 50 korral. 
Meemid kasutasid sageli viidet köhale kui ühele COVID-19 põhisümptomile. Inimesed hakkasid pandeemialaine ajal teisiti suhtuma ka tavalisse külmetusse, kahtlustades köhivaid kaaskodanikke koroonaviiruse põdemises. Joonisel 22 on koer, kes kikitab kõrvu, olles häiritud kellegi köhatamisest. Tekst lubab aimata, et möödujate hammustamine on koerale täiesti tavapärane tegevus, kuid selle on nüüd muutnud ohtlikuks koroonapandeemia puhkemine.

\section{Kiedy rowerzysta, którego właśnie ugryzłeś, zaczyna kaszleć...}

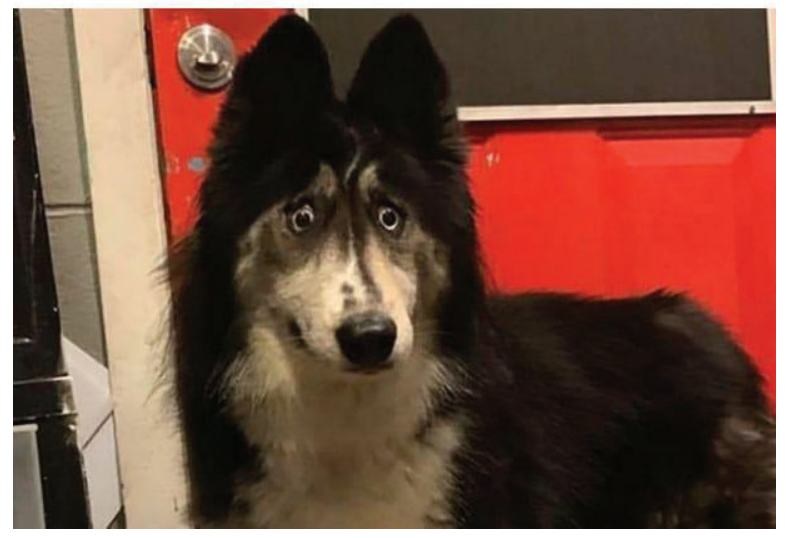

Joonis 22. Kui rattur, keda sa just hammustasid, hakkab köhima...

\section{Lõpetuseks}

Kõik meemid, mida käesolev artikkel kirjeldab, sisaldavad erinevaid intertekstuaalseid ja/või transmeedialisi vihjeid. Valisime sellised meemid, mis viitavad kohalikele kultuurinähtustele või poola huumoritraditsioonile (nt miilitsaanekdoodid), kuigi osa langeb kokku universaalsete teemadega (nt koeraga jalutamise õigus pandeemia ajal). Tüüpilisemad näited viitavad Poolas levinud kultuurilistele stereotüüpidele, kohalikule poliitikale (nt valimistele, mis pidid toimuma 10. mail 2020) ja usupühadele. Järgnevasse tabelisse koondasime 22 artiklis kirjeldatud meemi põhitunnused, et ilmestada nende intertekstuaalset keerukust ja mitmekesisust. 
Tabel. 1 Meemide analüüs.

\begin{tabular}{|c|c|c|c|}
\hline $\begin{array}{l}\text { Joonis } \\
\text { nr }\end{array}$ & Meemi tekst & $\begin{array}{l}\text { Intertekstuaalne } \\
\text { viide }\end{array}$ & Vihjed \\
\hline 1. & $\begin{array}{l}\text { Mul on küsimus. Ma } \\
\text { tahaksin küsida, kui } \\
\text { kaua me peame end } \\
\text { veel pesema? }\end{array}$ & $\begin{array}{l}\text { "Rejs" (Lõbusõit) } \\
(1970) \text { - poola film }\end{array}$ & $\begin{array}{l}\text { Pandeemiaaegsed } \\
\text { piirangud, } \\
\text { kätepesunõue; } \\
\text { maaelanike } \\
\text { harjumus pesta end } \\
\text { vaid pühapäeviti; } \\
\text { kommunistlik tööliste } \\
\text { koosolek }\end{array}$ \\
\hline 2. & $\begin{array}{l}\text { Saabunud on } \\
\text { kohutavad ajad, } \\
\text { härra. Inimesed } \\
\text { peavad käsi pesema, } \\
\text { toitu valmistama, } \\
\text { lastega rääkima. } \\
\text { Kui nii edasi läheb, } \\
\text { hakkavad nad varsti } \\
\text { ka raamatuid lugema. }\end{array}$ & $\begin{array}{l}\text { "Alternatywy 4" } \\
\text { (Neli alternatiivi), } \\
\text { osa 8: Abielu } \\
\text { (1982-1983)- } \\
\text { poola film }\end{array}$ & $\begin{array}{l}\text { Pandeemiaaegsed } \\
\text { piirangud; varjatud } \\
\text { kriitika ühiskonna } \\
\text { suhtes, mis üritab } \\
\text { kõrvale hoida oma } \\
\text { põhikohustustest; } \\
\text { kätepesu, } \\
\text { küpsetamine, } \\
\text { lastekasvatamine, } \\
\text { lugemine }\end{array}$ \\
\hline 3. & $\begin{array}{l}\text { Ma kordan, härra, } \\
\text { selle idee, et abielus } \\
\text { naine ja mees peaksid } \\
\text { kõndima teineteisest } \\
\text { kahemeetrist } \\
\text { distantsi hoides, } \\
\text { olgugi et nad kodus } \\
\text { kalduvad koos } \\
\text { magama, on kindlasti } \\
\text { välja mõelnud mingi } \\
\text { vana poissmees. }\end{array}$ & $\begin{array}{l}\text { "Alternatywy 4" } \\
\text { (Neli alternatiivi) - } \\
\text { poola film }\end{array}$ & $\begin{array}{l}\text { Pandeemiaaegsed } \\
\text { piirangud; sotsiaalse } \\
\text { distantsi hoidmine; } \\
\text { vana poissmees } \\
\text { Jarosław Kaczyński } \\
\text { ja tema vähene } \\
\text { arusaamine pereelust }\end{array}$ \\
\hline 4. & $\begin{array}{l}\text { Kurat! Esiteks } \\
\text { "Kuningate kroon", } \\
\text { nüüd koroonaviirus. } \\
\text { Persse! Kui koroona- } \\
\text { Zenek tuleb, on } \\
\text { maailma lõpp käes. }\end{array}$ & $\begin{array}{l}\text { Teleseriaal } \\
\text { "Korona Królów" } \\
\text { (Kuningate kroon) } \\
\text { kuningatest; } \\
\text { poplaulja Zenek } \\
\text { Martyniuk }\end{array}$ & $\begin{array}{l}\text { Pidev pandeemia- } \\
\text { teemaline infovoog } \\
\text { meedias; ajalooline } \\
\text { kostüümidraama; } \\
\text { poplaulja, disko-polo } \\
\text { stiili esindaja, keda } \\
\text { reklaamib valitsus }\end{array}$ \\
\hline 5. & $\begin{array}{l}\text { Joo viina, istu oma } \\
\text { perse peal ja ükski } \\
\text { viirus ei kimbuta } \\
\text { sind. }\end{array}$ & $\begin{array}{l}\text { "Janosik" (1974) - } \\
\text { poola film }\end{array}$ & $\begin{array}{l}\text { Koroonaviiruse } \\
\text { oht; mägismaalaste } \\
\text { arvamused, murrak, } \\
\text { stereotüübid (joomine, } \\
\text { laiskus); alkoholi } \\
\text { antiseptiline omadus }\end{array}$ \\
\hline
\end{tabular}




\begin{tabular}{|c|c|c|c|}
\hline 6. & $\begin{array}{l}\text { Kunstnik üritab } \\
\text { sekkuda, pildiallkiri } \\
\text { puudub }\end{array}$ & $\begin{array}{l}\text { Jacek Malczewski } \\
\text { (1854-1929) } \\
\text { maal "Malarczyk" } \\
\text { (Kunstnik) (1890) }\end{array}$ & $\begin{array}{l}\text { Pandeemiaaegne } \\
\text { keeld istuda } \\
\text { pinkidel, lahkuda } \\
\text { kodust, kohustus } \\
\text { kanda näomaski; } \\
\text { rumala politseiniku } \\
\text { stereotüüp }\end{array}$ \\
\hline 7. & $\begin{array}{l}\text { Politsei: "Mis on } \\
\text { teie reisi eesmärk?" } \\
\text { Naine hobuse seljas: } \\
\text { "Ma lihtsalt hullun } \\
\text { juubeldusest." }\end{array}$ & $\begin{array}{l}\text { Władysław Podko- } \\
\text { wiński (1866- } \\
\text { 1895) maal "Szał } \\
\text { uniesień" (Hullunud } \\
\text { juubeldus) (1894) }\end{array}$ & $\begin{array}{l}\text { Pandeemiaagsed } \\
\text { reisimispiirangud; } \\
\text { rumala politseiniku } \\
\text { stereotüüp }\end{array}$ \\
\hline 8. & $\begin{array}{l}\text { Krakówis kandsime } \\
\text { me maske juba enne } \\
\text { kui see populaarseks } \\
\text { sai. }\end{array}$ & $\begin{array}{l}\text { Foto Krakówi } \\
\text { linnast, } \\
\text { rahvariides } \\
\text { inimesed }\end{array}$ & $\begin{array}{l}\text { Pandeemiaaegne } \\
\text { kohustus kanda } \\
\text { näomaski; sudu } \\
\text { Krakówis; pikaajaliste } \\
\text { traditsioonidega } \\
\text { linn, varasem Poola } \\
\text { pealinn; rahvariided }\end{array}$ \\
\hline 9. & $\begin{array}{l}\text { Te ei tohiks väljuda. } \\
\text { Kas maksate } 500 \\
\text { zlotti või läheme } \\
\text { kohtusse? }\end{array}$ & Usukombed & $\begin{array}{l}\text { Pandeemiaaegne } \\
\text { keeld tähistada } \\
\text { lihavôtteid laiendatud } \\
\text { perekonna ringis } \\
\text { ja kodust lahkuda; } \\
\text { rumala politseiniku } \\
\text { stereotüüp }\end{array}$ \\
\hline 10. & $\begin{array}{l}\text { Kazimierz - Przerwa } \\
\text { (Paus) - Tetmajer }\end{array}$ & $\begin{array}{l}\text { Poola modernistlik } \\
\text { luuletaja (1865- } \\
\text { 1940) }\end{array}$ & $\begin{array}{l}\text { Pandeemiaaegsed } \\
\text { piirangud; sotsiaalse } \\
\text { distantsi hoidmise } \\
\text { kohustus ühistrans- } \\
\text { pordis; poola kirjan- } \\
\text { dusajaloo alased kooli- } \\
\text { teadmised; luuletaja } \\
\text { perekondlik taust }\end{array}$ \\
\hline 11. & $\begin{array}{l}\text { Nii et sa siis ütled, et } \\
\text { nad sulgesid riigipiiri } \\
\text { 13ndal? }\end{array}$ & $\begin{array}{l}\text { Kindral Wojciech } \\
\text { Jaruzelski (1923- } \\
\text { 2014) }\end{array}$ & $\begin{array}{l}\text { Poola piiride sulge- } \\
\text { mine 13. märtsil } 2020 \text {; } \\
\text { sõjaolukorra välja- } \\
\text { kuulutamine } 13 \text {. det- } \\
\text { sembril 1981; kindral } \\
\text { Jaruzelski kui diktaa- } \\
\text { tor; sõjavägi tänavatel, } \\
\text { suletud piirid, oht } \\
\text { Venemaa poolt }\end{array}$ \\
\hline
\end{tabular}




\begin{tabular}{|c|c|c|c|}
\hline 12. & $\begin{array}{l}\text { Epideemia - } \\
\text { talongikaart }\end{array}$ & $\begin{array}{l}\text { Toidutalongid } \\
\text { sotsialismiajastu } \\
\text { Poolas }\end{array}$ & $\begin{array}{l}\text { Pandeemiaaegsed } \\
\text { piirangud } \\
\text { jalutuskäikudele, } \\
\text { ostlemisele; PIS } \\
\text { valitsuse autoritaarne } \\
\text { stiil alates } 2015 ; \\
\text { sotsialismiajastu } \\
\text { toidupuudus, } \\
\text { pealekaebamine }\end{array}$ \\
\hline 13. & $\begin{array}{l}\text { Riigid, kus } \\
\text { valimised on edasi } \\
\text { lükatud. Riigid, kus } \\
\text { plaanitakse valimisi } \\
\text { korraldada. }\end{array}$ & $\begin{array}{l}\text { Maailma valimiste } \\
\text { libakaart }\end{array}$ & $\begin{array}{l}\text { Planeeritud valimised } \\
\text { Poolas } 10 . \text { mail } \\
\text { 2020; edasilükatud } \\
\text { valimised } \\
\text { teistes riikides; } \\
\text { maailmapoliitika }\end{array}$ \\
\hline 14. & $\begin{array}{l}\text { Globaalse tõsise } \\
\text { olukorra tõttu toimub } \\
\text { 1. aprill sel aastal } \\
\text { 10. mail. }\end{array}$ & Avalik teadaanne & $\begin{array}{l}\text { 10. mai } 2020 \text { valimised } \\
\text { Poolas; aprillinali }\end{array}$ \\
\hline 15. & $\begin{array}{l}\text { Poolakad urni/ } \\
\text { valmiskasti juurde!" } \\
\text { [President] Andrzej } \\
\text { Duda palub teid. }\end{array}$ & Libareklaam & $\begin{array}{l}\text { Viirusoht; 10. mai } \\
\text { valimised Poolas; } \\
\text { president ja } \\
\text { presidendikandidaat } \\
\text { Andrzej Duda }\end{array}$ \\
\hline 16. & $\begin{array}{l}\text { Esmaspäev Poola } \\
\text { metsas }\end{array}$ & Libauudis & $\begin{array}{l}\text { Pandeemiaaegne } \\
\text { sotsiaalsete } \\
\text { kogunemiste keeld; } \\
\text { sotsiaalse distantsi } \\
\text { hoidmise reegel; } \\
\text { keeld käia metsas; } \\
\text { keelu pihta suunatud } \\
\text { meediakriitika }\end{array}$ \\
\hline 17. & $\begin{array}{l}\text { Valimised maikuus? } \\
\text { Jarek [=Jarosław } \\
\text { Kaczynski], meie } \\
\text { lugupidamine! }\end{array}$ & $\begin{array}{l}\text { Poliitikute (Putini } \\
\text { ja Lukašenka) foto }\end{array}$ & $\begin{array}{l}\text { 10. mai valimised } \\
\text { Poolas; autoritaarsed } \\
\text { naaberriikide juhid; } \\
\text { Kaczyński kui } \\
\text { autoritaarne juht }\end{array}$ \\
\hline 18. & $\begin{array}{l}\text { Kass: "Nii et ma } \\
\text { peaksin, mask peas, } \\
\text { hiiri püüdma?" }\end{array}$ & Foto kassist & $\begin{array}{l}\text { Pandeemiaaegsed } \\
\text { piirangud; näomaski } \\
\text { kasutamise nõue, mille } \\
\text { täitmata jätmise eest } \\
\text { teeb politsei trahvi; } \\
\text { rumala politseiniku } \\
\text { stereotüüp }\end{array}$ \\
\hline
\end{tabular}




\begin{tabular}{|l|l|l|l|}
\hline 19. & $\begin{array}{l}\text { Inimesed! Kas teiega } \\
\text { on kõik korras? }\end{array}$ & Loomameem & $\begin{array}{l}\text { Inimeste muutunud } \\
\text { käitumine pandeemia } \\
\text { ajal; näomaskide } \\
\text { kandmise ja kodus } \\
\text { püsimise nõue }\end{array}$ \\
\hline 20. & $\begin{array}{l}\text { Mis toimub? Miks } \\
\text { inimesed suukorviga } \\
\text { käivad? }\end{array}$ & Loomameem & $\begin{array}{l}\text { Inimeste muutunud } \\
\text { käitumine pandeemia } \\
\text { ajal; näomaskide } \\
\text { kandmise nõue }\end{array}$ \\
\hline 21. & $\begin{array}{l}\text { See on Szarik, } \\
\text { ainuke koer meie } \\
\text { 16korruselises } \\
\text { kortermajas. Teda on } \\
\text { täna jalutama viidud } \\
\text { 50 korral. }\end{array}$ & $\begin{array}{l}\text { Loomameem, poola } \\
\text { (Neli tankisti ja }- \text { "Czterej } \\
\text { koer) } \text { (1966-1970) }\end{array}$ & $\begin{array}{l}\text { Pandeemiaaegsed } \\
\text { piirangud: oue võib } \\
\text { minna ainult koeraga } \\
\text { jalutamiseks; Szarik: } \\
\text { tankimeeskonna hea } \\
\text { kaaslane filmist “Neli } \\
\text { tankisti ja koer" }\end{array}$ \\
\hline 22. & $\begin{array}{l}\text { Kui rattur, keda sa } \\
\text { just hammustasid, } \\
\text { hakkab köhima. }\end{array}$ & Loomameem & $\begin{array}{l}\text { Köha kui COVID-19 } \\
\text { sümptom; hirm } \\
\text { nakatuda }\end{array}$ \\
\hline
\end{tabular}

Huumorimehhanismid kasutavad intertekstuaalseid viiteid filmidele, teleseriaalidele, luulele, maalikunstile, poliitilistele sündmustele ja poliitikutele, uudistele jm. Huumor võib avalduda erinevas vormis: loomameemid, karikatuurid, reklaamid, libauudised, avalikud teadaanded, fotod, infograafika jm. Naljaloojate tähelepanu on pööratud ka rahvus- ja kohalikele stereotüüpidele, Poola ajaloole, valitsenud klassisüsteemile, sotsialistlikule perioodile ajaloos, loomade ja inimeste vahelistele suhetele. Niisiis, kõik meemid toimivad kahel tasemel: kontekstuaalne ja päevakajaline COVID-19 pandeemia teema ja vihjeline taustainfo, millest osa on arusaadav vaid väga kitsale publikule.

Meemides väljenduv loovus näitab kultuurimälu tohutut potentsiaali. Selles säilitatakse ja kogutakse lugusid ja motiive ning need taasilmuvad pidevalt uutes kultuuritekstides (Wójcicka 2019). Poolakate kollektiivses mälus talletatud ja pidevas taaskasutuses ringlev kultuuriline info annab lootust rasketel aegadel, tugevdab kogukondlikku ühtsust ja ründab pandeemiahirmu naeru abil.

Tõlkinud Liisi Laineste 


\section{Ciekawe jak długo będziemy się śmiać z żartów o koronawirusie}
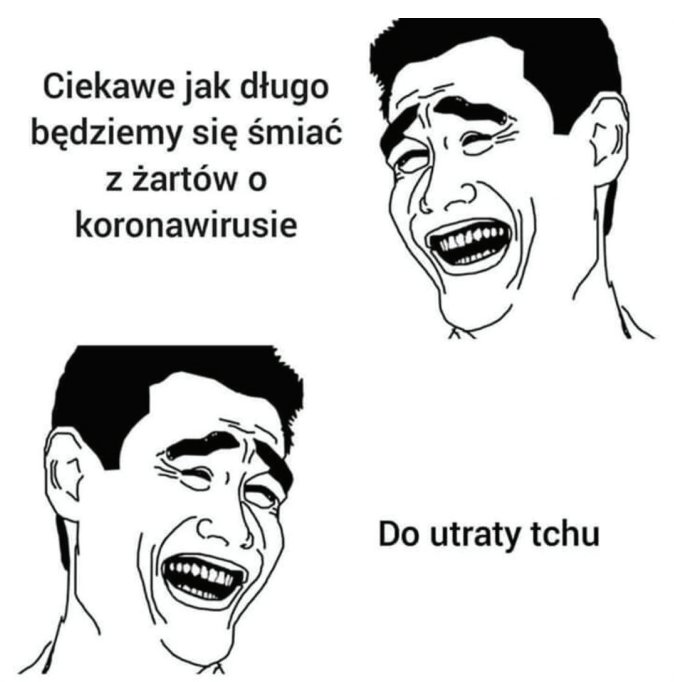

\section{Do utraty tchu}

Joonis 23. "Ei tea, kui kaua me koroona-viiruse naljade üle veel naerame." - "Niikaua, kuni enam ei hinga."

\section{Kommentaarid}

1 Bareismidele on pühendatud spetsiaalne Facebooki grupp "Bareismid alati jäävad": https://www.facebook.com/bareizmy (vaadatud 12.03.2021).

2 Disko-polo on lihtsate sõnade ja meloodiaga muusikastiil.

3 Rumala politseiniku/miilitsa tegelaskuju on üsna sarnane Itaalia carabinieri stereotüübile (vt Chiaro 2017), sest ka siin viidatakse varjatult harimatute, maalt pärit politseinike töölevõtmisele kommunistlikus Poolas pärast 1945. aastat.

4 Aadliseisus ja sellega kaasneva vapi omamine oli vanas Poolas väga prestiižne. Przerwa-nimelist vappi aga ei eksisteerinud. Sellele lähedasim oli Przerowa, mis antud perekonnaga seotud ei olnud.

5 Seda uskumust tugevdab seegi, et näiteks toimus atendaadikatse Johannes Paulus II-le just 13. mail 1981, mil kõikjal riigis peeti püha Fatima ilmutuspäeva (13. mai 1917) pidustusi.

${ }^{6}$ Sõnamängu aluseks on asjaolu, et sõna urn tähistab nii anumat surnu tuha säilitamiseks kui ka valimiskasti. 


\section{Kirjandus}

Brzozowska, Dorota \& Chłopicki, Władysław (toim) 2012. Polish humour. Krakow: Tertium.

Brzozowska, Dorota \& Chłopicki, Władysław 2019. The Chinese as targets in Polish humorous discourse. Humor: International Journal of Humor Research 32 (2), lk 235-265 (doi: 10.1515/humor-2018-0052).

Chiaro, Delia 2017. "Vivi Pericolosamente": Christie Davies, Italians and dangerous things. Special issue on playing with aggression. In memoriam Christie Davies. The European Journal of Humour Research 5 (4), lk 41-50 (doi: 10.7592/EJHR2017.5.4.chiaro).

Chłopicki, Władysław 2017. Humor and narrative. Attardo, Salvatore (toim). The Routledge handbook of language and humor. Routledge Handbooks in Linguistics. New York, London: Routledge, lk 143-157.

Chłopicki, Władysław \& Brzozowska, Dorota 2017. Polish highlander jokes and their targets. The European Journal of Humour Research 5 (4), lk 67-84 (doi: 10.7592/ EJHR2017.5.4.chlopicki).

Coulson, Seana 2015. No one will ever wonder why, they said: Conceptual blending and humorous memes cross the road, they said. Paper presented at the International Society of Humour Studies Conference. Oakland, CA, USA, 29 June - 3 July.

Davies, Christie 1998. Jokes and their relation to the society. Humor research 4 . Berlin \& New York: Mouton de Gruyter (doi: 10.1515/9783110806144).

Davies, Christie 2011. Jokes and targets. Bloomington: Indiana University Press.

Davis, Dineh 2008. Communication and humor. Raskin, Victor (toim). The primer of humor research. Berlin \& New York: De Gruyter, lk 543-568.

Genette, Gerard 1997. Palimpsests: Literature in the second degree. Lincoln, NB: University of Nebraska Press.

Knobel, Michele \& Lankshear, Colin 2005. Memes and affinities: Cultural replication and literacy education. Paper presented to the annual NRC, Miami, November 30 (https:// www.researchgate.net/publication/249902174_Memes_and_affinities_Cultural_replication_and_literacy_education - 17. märts 2021).

Krikmann, Arvo \& Laineste, Liisi (toim) 2009. Permitted laughter: socialist, post-socialist and never-socialist humour. Tartu: ELM Scholarly Press.

Laineste, Liisi 2012. They didn't batter us enough: Soviet nostalgia in post-socialist humour. Paper presented at the conference Humour in conventional and unconventional politics, November 5-9, Galati, Romania.

Laineste, Liisi \& Voolaid, Piret 2016. Laughing across borders: Intertextuality of internet memes. The European Journal of Humour Research 4 (4), lk 26-49 (doi: 10.7592/ EJHR2016.4.4.laineste).

Lanir, Lesley 2019. What is transtextuality? Understanding the meaning of the words we read (https://medium.com/@llanirfreelance/what-is-transtextuality-understandingthe-meaning-of-the-words-we-read-f89886f90c67 - 17. märts 2021). 
Norrick, Neal 1989. Intertextuality in humor, Humor: International Journal of Humor Research 2 (2), lk 117-139 (doi: 10.1515/humr.1989.2.2.117).

Norrick, Neal 2014. Joking relationship. Attardo, Salvatore (toim). Encyclopedia of Humor Studies. Los Angeles: Sage, lk 418-421.

Norström, Roża \& Sarna, Paweł 2021. Internet memes in Covid-19 lockdown times in Poland. Comunicar 29 (67) (doi: 10.3916/C67-2021-06).

Ross, Alison 1998. The Language of Humour. London: Routledge.

Ryan, Marie-Laure 2008. Transmedial storytelling and transfictionality. Pier, John \& Landa, Jose Angel Garcia (toim). Theorizing narrativity. Berlin, New York: De Gruyter, lk 385-417 (doi: 10.1515/9783110969801).

Shifman, Limor 2014. Internet humor. Attardo, Salvatore (toim). Encyclopedia of Humor Studies. Los Angeles: Sage, lk 389-392.

Spiridon, Monica 2015. Remediality: Cultural discourse in the era of "Technological Neo-Enlightenment”. Philologica Jassyensia XI, 1 (21), lk 259-266.

Tsakona, Villy \& Chovanec, Jan 2020. Revisiting intertextuality and humour: Fresh perspectives on a classic topic. The European Journal of Humour Research 8 (3), lk 1-16 (doi: 10.7592/EJHR2020.8.3.Tsakona).

Wójcicka, Marta 2019. Mem internetowy jako multimodalny gatunek pamięci zbiorowej. Lublin: Wydawnictwo Uniwersytetu Marii Curie-Skłodowskiej.

\title{
Summary
}

\section{Polish intertextual memes during the COVID pandemic}

\author{
Dorota Brzozowska \\ Professor \\ Institute of Linguistics, University of Opole \\ dbrzozowska@uni.opole.pl \\ Władysław Chłopicki \\ Professor of Linguistics \\ Department of English Studies, Jagiellonian University \\ w.chlopicki@uj.edu.pl
}

Keywords: COVID restrictions, intertextuality, memes, socialism, stereotypes

The aim of the paper is to show the Polish story of the COVID-19 pandemic as seen through a humorous looking glass. Different stages of coronavirus presence in the media and social discourse have been accompanied by the appearance and development of jokes and memes, which illustrate the rapidly changing pandemic situation. The database consists of over three hundred memes, movies, 
and comments collected between February and May 2020, during the pandemic humour peak, and come mainly from private WhatsApp and Facebook accounts of the researchers. The humorous material is related to introduced restrictions, changing laws, parliamentary elections, news from other affected countries as well as seasons and festive times - especially Easter - occurring in the same period of time. The universal themes present in the humorous material travelling around the world are complemented by the strictly culturally immersed topics, reflecting the specific social and political situation in Poland. The analysis undertaken in the article focuses on various kinds of mechanisms which involve intertextuality (allusions) as well as complexity of references that function as sources of humour, with special attention being paid to cultural references, for example, films, paintings, references to political life, including those of the life under socialism as well as universal themes, such as animal memes.

Dorota Brzozowska (PhD) on Poola Opole Ülikooli keeleteaduse instituudi korraline professor. Tema teaduslikud huvid hõlmavad huumori, stilistika ja diskursuse analüüsi, kultuuridevahelise suhtlemise ja semiootika uurimist. Neil teemadel on temalt ilmunud ka kolm poolakeelset monograafiat.

Dorota Brzozowska, $\mathrm{PhD}$ in linguistics, is Full Professor at the Institute of Linguistics of the University of Opole, Poland. Her scholarly research interests comprise research on humour, stylistics, discourse analysis, intercultural communication, and semiotics. She has authored the following books in Polish: On Polish and English Jokes: A Linguistic and Cultural Analysis (2000), Polish Ethnic Joke: Stereotype and Identity (2008), and Chinese Traces in Polish Contemporary Discourses (2018).

dbrzozowska@uni.opole.pl

Władysław Chłopicki on Poola Krakówi Jagielloniani Ülikooli inglise keele osakonna keeleteaduse professor. Tema akadeemiliste huvide hulka kuuluvad interdistsiplinaarsed huumoriuuringud kultuuriuuringute, kognitiivse lingvistika, keelelise pragmaatika ja narratoloogia kontekstis ning tõlkeuuringud. Ta on kirjutanud arvukalt peamiselt huumoriuuringutega seotud artikleid ja poolakeelseid huumoriuuringute monograafiaid. Samuti on ta kaastoimetanud üle tosina huumori, kultuuridevahelise suhtlemise, suhtlusstiilide ja lingvistika monograafia, sealhulgas sarja "Huumor ja kultuur" (kirjastus Tertium). 
Władysław Chłopicki is Professor of Linguistics at the Department of English Studies at the Jagiellonian University in Kraków, Poland. His academic interests include interdisciplinary humour research in the context of cultural studies, cognitive linguistics, linguistic pragmatics and narratology as well as translation studies. He has authored numerous articles mainly related to humour studies and a Polish-language monograph on humour research. He has also co-edited more than a dozen monographs on humour, inter-cultural communication, communication styles and linguistics, including the series Humour and Culture (by Tertium Publishers).

w.chlopicki@uj.edu.pl 